\title{
36. COMMISSION DE LA SPECTROPHOTOMETRIE
}

PrÉsident: M. D. Chalonge.

Membres: MM. Adam, Adel, L. H. Aller, H. W. Babcock, E. A. Baker, Barber, Barbier, Biermann, W. Becker, Beals, Brück, Chandrasekhar, Code, de Jager, A. N. Deutsch, Dufay, Dunham, D. S. Evans, Goldberg, Gratton, Greaves†, Greenstein, J. S. Hall, Hiltner, Henyey, Hitotuyanagi, Houtgast, Hunaerts, Hunter, Mlle Iwanowska, MM. Järnefelt, J. J. Johnson, Kienle, R. B. King, Kozyrev, Kuprevich, Kourganoff, Kuiper, Labs, Lindblad, McCrea, McKellar, Melnikov, Menzel, Minkowski, Minnaert, G. Münch, Mustel, Öhman, Pannekoek, Pecker, A. K. Pierce, Plaskett, Rahman, Righini, Rudkjøbing, Saha†, Schwarzschild, Shajn†, Sobolev, Spitzer, Stebbins, Strassl, Strömgren, Struve, Suemoto, ten Bruggencate, Thackeray, R. N. Thomas, Mlle Underhill, MM. Unsöld, Wempe, Weston, O. C. Wilson, R. Wilson, Whitford, Woolley, K. O. Wright, Wrubel, Yü.

\section{6a. Sous-Commission Des Etalons D'Intensités de Raies}

PRÉSIDENT: M. K. O. Wright.

Membres: MM. Greenstein, Hiltner, Houtgast, Pecker, Plaskett, Righini.

\section{6b. Sous-commission pour la ThÉorie des Atmosphères Stellaires}

Président: M. A. Unsöld.

Membres: MM. Barbier, Biermann, Chandrasekhar, de Jager, Goldberg, Henyey, Kozyrev, Kourganoff, Labs, Menzel, Minnaert, G. Münch, Plaskett, Rudkjøbing, Saha†, Sobolev, Spitzer, Strömgren, R. N. Thomas, Mlle Underhill, M. Wrubel.

Ce rapport est rédigé de façon analogue à celui présenté en 1952 au Congrès de Rome. Il y est examiné plus spécialement les nouveautés et les progrès dans les techniques et dans les méthodes utilisées pour les observations spectrophotométriques et pour l'étude des résultats d'observation. Quant aux sujets étudiés, ils se rapportent surtout aux spectres continus; il n'a été possible que de passer brièvement en revue les travaux, beaucoup plus nombreux, relatifs aux raies.

\section{SPECTROGRAPHES}

Deux spectrographes solaires ont été décrits. Le premier, celui de l'observatoire d'Oxford, est présenté par H. H. Plaskett qui indique en particulier ses défauts et les moyens de les corriger.

Le second est en construction à l'observatoire McMath; c'est un grand spectrographe de I 8 mètres, à réseau, et sa caractéristique la plus remarquable réside en ce que l'on fait le vide dans le vaste récipient que le contient, afin d'éviter les perturbations dues aux mouvements de l'air. L'organe sensible est un photomultiplicateur qui enregistrera directement l'intensité dans le spectre. Le pouvoir de résolution doit être de l'ordre d'un demi million. L'instrument servirait en particulier à l'étude des contours de raies aux divers points du disque solaire.

Un organe nouveau commence à apparaître dans les spectrographes stellaires: un photomètre qui mesure le flux moyen entrant dans la fente et permet de déterminer le temps d'exposition. Un tel dispositif a été mis au point par Babcock au Mont Wilson. 


\section{TravauX DE Recherches}

\section{Spectrophotométrie photographique}

Dans les périodiques consacrés à l'astrophysique il y a peu à signaler sur la technique photographique à part une étude comparative des principales émulsions photographiques allemandes par Paetzold et des recherches de Makarova sur l'influence de la densité du fond de la plaque sur les mesures d'intensité, et de Hansson sur l'influence du révélateur sur le pouvoir de résolution de l'image photographique.

La gradation de la Iumière a été l'objet de nouvelles recherches à l'Institut d'Astrophysique de Paris: les propriétés absorbantes du quartz cristallisé utilisé pour la construction des pièces optiques, bien que très faibles au dessus de $3000 \AA$, peuvent suffire pour produire une absorption très appréciable pour les rayons ultraviolets qui passent au voisinage de la base du prisme et il en résulte des difficultés dans l'emploi de diverses méthodes de gradation; on peut préconiser comme procédé insensible à ce défaut l'emploi d'un secteur tournant d'ouverture variable, centré sur la lentille collimatrice.

Dobronravin a décrit un dispositif pour élargir automatiquement les spectres obtenus au prisme objectif; cet appareillage est adaptable à n'importe quel astrographe.

Hossack a construit un microphotomètre oscilloscopique dont le but est particulier: il permet la comparaison visuelle rapide et cependant précise des raies de deux spectres stellaires en vue par exemple de déterminer un rapport de deux raies, critère de classification. Cette méthode, plus rationnelle que la simple estimation visuelle, n'est cependant pas rigoureusement quantitative.

Des méthodes graphiques permettant le dépouillement rapide d'enregistrements microphotométriques de spectres ont été imaginées par Dobronravin. Un appareillage mécanique répondant au même but fonctionne actuellement à l'observatoire de Pulkovo.

\section{Spectrophotométrie photoélectrique}

Il n'est pas inutile de mentionner ici les nouveaux modèles de photomètres photoélectriques puisque de tels instruments peuvent permettre de faire de la photométrie en plusieurs couleurs qui marque une nette évolution de la photométrie vers la spectrophotométrie. Plusieurs de ces instruments ont été construits, en particulier celui de Nikonov et Nikonova à Siméis.

D'autre part on s'efforce, de divers côtés, de construire des spectrographes photoélectriques pour l'exploration directe du spectre à l'aide d'une cellule ou d'un multiplicateur. Le spectrographe à prisme objectif à optique de quartz utilisé par Melnikov et ses collaborateurs pour l'étude des fonds continus stellaires a été muni d'un dispositif photoélectrique et peut déjà enregistrer directement des spectres d'étoiles brillantes.

Whitford et Code étudient au Mont Wilson la distribution de l'énergie dans les spectres stellaires à l'aide d'un spectrographe à réseau et à miroirs dont l'organe sensible est un photomultiplicateur; la rotation du réseau fait défiler le spectre sur le multiplicateur. L'intervalle spectral étudié s'étend de 3200 à roooo $\AA$. La précision est comparable à celle de la photométrie photoélectrique.

P. Guérin met au point un spectrophotomètre imaginé par Laffineur: cet appareil comprend un spectrographe à fente et deux photomultiplicateurs dont l'un mesure le flux total de lumière pénétrant dans l'instrument et l'autre explore le spectre. Un logomètre mesure à chaque instant le rapport du second courant au premier. Ce dispositif annule ainsi les effets de la scintillation et les résultats obtenus sont très satisfaisants.

Un dispositif de mesure directe de l'intensité du spectre solaire utilisant deux photomultiplicateurs est en cours d'installation au spectrographe solaire à réseau de l'observatoire Dunsink.

Link et Neuzil ont construit un dispositif photoélectrique pour l'observation rapide des profils de raies (adapté en particulier au spectrohélioscope). 


\section{Sources de comparaison}

La source luminescente (mélange de poudres microcristallines excitées par la raie de résonance du mercure) donnant un spectre continu allant du rouge à l'ultraviolet qui a déjà été mentionnée dans le rapport de I952, a été étudiée par Guérin. Elle semble pouvoir constituer un étalon secondaire de répartition énergétique.

Kienle continue l'étude de la lampe au xénon à grande brillance.

Comme étalon primaire de répartition énergétique on emploie non seulement le corps noir mais le cratère positif de l'arc au charbon. Cette dernière source a fait l'objet de recherches diverses dans le but d'en préciser la courbe d'énergie.

\section{Spectrophotométrie des spectres continus}

\section{Photométrie de plusieurs couleurs}

La photométrie photoélectrique de plusieurs couleurs (trois couleurs particulièrement) qui est une première forme grossière de spectrophotométrie, connaît un grand développement. Elle a permis en particulier à Morgan et Johnson de donner aux règles de la classification stellaire de Yerkes une forme photométrique applicable à des étoiles plus faibles.

Stebbins et Kron poursuivent leurs études de photométrie en six couleurs et ont déjà rassemblé les données concernant 400 étoiles (non encore publiées). Grâce à cette photométrie en six couleurs ils ont pu mettre en évidence des variations de couleur faibles mais sûres, pour des étoiles variables telles que $\beta$ Cep dont l'amplitude est très faible.

La qualité des données de la photométrie en six couleurs de Stebbins et Whitford est si bonne que $\mathrm{D}$. Barbier a pu en déduire une méthode de détermination de la discontinuité de Balmer. Mlle Divan a fait, à partir de ces données photométriques en six couleurs, une détermination très précise des propriétés absorbantes de la matière interstellaire, uniformes dans toutes les directions; améliorant la méthode de Barbier, elle a pu étendre le procédé de calcul de la discontinuité de Balmer à partir de la photométrie en six couleurs, aux étoiles des tout premiers types, mettant même en évidence, sur le simple examen des résultats des observations de Stebbins et Whitford, plusieurs étoiles à émission (que les observations directes ont confirmées).

\section{Spectrophotométrie stellaire relative}

Les observations de spectrophotométrie relative (comparaison d'une étoile inconnue à une étoile dont le spectre est quantitativement connu) fournissent les gradients relatifs et les discontinuités de Balmer. Elles sont poursuivies systématiquement à l'Institut d'Astrophysique de Paris en vue d'augmenter la précision avec laquelle sont connues ces quantités. Mais peu de résultats ont été publiés au cours des trois dernières années. Parmi les résultats annoncés on peut citer ceux de Mlle Divan concernant les étoiles des types $\mathrm{O}_{5}$ à $\mathrm{B}_{3}$ : le gradient de ces étoiles pour la région bleue-violette semble très sensiblement le même; autrement dit la température de couleur qui croît lorsqu'on passe des types avancés aux premiers types semble se stabiliser et demeurer constante lorsqu'on va, au delà de $\mathrm{B}_{3}$, vers les premiers sous-types $\mathrm{O}$.

Tcheng Mao-Lin et Mlle Bloch poursuivent leurs déterminations des discontinuités de Paschen des étoiles brillantes.

Whitford et Code ont fait des déterminations de spectrophotométrie relative avec leur spectrographe photoélectrique à réseau fixé au foyer des télescopes de 60 et de roo pouces du Mont Wilson. Les étoiles de comparaison sont $\alpha$ Lyrae, $\alpha$ Cygni et $\gamma$ Cygni (ce qui laisse supposer que les études sont limitées pour l'instant à une certaine portion du ciel) et les comparaisons se font dans tout le vaste domaine 3200-Io000 $\AA$.

Une série d'études a été faite par divers astronomes soviétiques: Mirzoian a déterminé les gradients de 34 étoiles des types O, B et A; Raitburd a fait l'étude spectrophoto- 
métrique de $\lambda$ Cep et Dadaev celle de deux binaires à éclipses A o Cas et $\beta$ Lyr; Melnikov analyse le spectre de nombreuses étoiles de types voisins de Ao.

\section{Spectrophotométrie stellaire absolue}

Les progrès de la théorie des atmosphères stellaires rend nécessaire une connaissance plus précise des échelles des températures de couleur (ou des gradients absolus) des différents types spectraux. Divers travaux ont été entrepris dans le but de les améliorer.

Pour passer de leurs déterminations spectrophotométriques relatives à des déterminations absolues Whitford et Code ont comparé plusieurs étoiles de leur programme à une lampe étalon dont l'étude avait été faite préalablement à l'aide d'un thermocouple 'noir'. Ces étoiles sont également comparées au Soleil.

Stebbins et Kron se proposent également de faire une détermination photoélectrique de l'échelle des températures stellaires.

Le groupe de l'Institut d'Astrophysique de Paris a repris au Jungfraujoch une série de comparaisons absolues entre quelques étoiles standard et une source terrestre (source fluorescente comparée au corps noir). Le travail est en cours. Une première partie de l'étude semble montrer que le fond continu des étoiles des premiers types présente une petite cassure (signalée par les auteurs allemands il y a longtemps) vers $4800 \AA$ accompagnée d'une faible discontinuité: le log de l'intensité augmente d'environ 0,03 lorsqu'on traverse cette discontinuité dans le sens bleu-rouge. La cassure et la discontinuité s'affaiblissent au delà du type $\mathrm{A}$, lorsqu'on se déplace vers les types plus avancés, si bien que les étoiles $F$ avancées et les étoiles $G$ présentent un fond continu visible qui est, dans son ensemble, beaucoup plus voisin de celui du corps noir que pour les étoiles des premiers types.

Pilowski a poursuivi et étendu ses travaux relatifs à la détermination des températures de brillance stellaires; il en utilise les résultats à l'évaluation des températures effectives.

La méthode suggérée par D. Chalonge et L. Divan pour l'estimation des températures superficielles, des températures de brillance et des diamètres apparents stellaires à partir de la mesure des profondeurs des premières raies de Balmer est toujours à l'étude à l'Institut d'Astrophysique de Paris. Elle a été employée en particulier à la détermination de la loi d'assombrissement centre-bord de la composante brillante d'Algol.

Vandekerkhove a décrit une méthode spectrophotométrique de détermination des rayons stellaires, très voisine de celle proposée dans les travaux précédents.

\section{Spectrophotométrie solaire}

Plusieurs travaux ont trait à la distribution de l'énergie dans les parties du fond continu solaire qui n'avaient pratiquement pas été étudiées jusqu'ici. Pierce a mesuré la répartition de l'énergie dans le proche infrarouge, entre Ioooo et $25000 \AA$; d'autre part Clearman et le groupe Wilson-Tousey-Johnson-Moore ont prolongé la courbe d'énergie vers l'extrême ultraviolet, au dessous de $3000 \AA$, à partir des spectres obtenus en fusées. La source de comparaison était en général un arc, dans les deux cas. Mais les évaluations concernant l'ultraviolet n'ont encore qu'un caractère assez grossier et c'est le spectre dans son ensemble qui est étudié (continu et raies) et non le fond continu seul, très difficile à isoler.

L'assombrissement centre-bord du disque solaire a été mesuré par Peyturaux entre la limite ultraviolette et $23000 \AA$; Pierce a fait des déterminations dans un domaine plus limité, de 8000 à $24000 \AA$, mais avec un instrument plus dispersif et les a prolongées jusque très près du bord. Dans les deux cas l'organe sensible de l'appareil était une cellule au sulfure de plomb.

D’autres auteurs (Righini, Ballario, Godoli, Heyden) ont profité d'une éclipse de Soleil pour étudier l'assombrissement.

\section{Nébuleuses, matière interstellaire}

Le travail le plus étendu sur le sujet de la matière interstellaire semble être celui de L. Divan. Mlle Divan a montré que la loi d'absorption continue par la matière interstellaire 
semble très bien définie et toujours la même dans les diverses directions de la Galaxie et en particulier dans la région centrale de la nébuleuse d'Orion ou l'on avait cru trouver une anomalie d'absorption.

\section{Planètes, satellites}

Hess a étudié des particularités de l'absorption atmosphérique de Jupiter et de Saturne.

Kozyrev a mis en évidence deux bandes d'absorption dans le spectre de Vénus; elles sont absentes dans Mars mais se retrouvent avec une intensité plus faible, dans le spectre de l'atmosphère terrestre. L'origine de ces bandes est encore inconnue.

Vigroux a mesuré les différences de répartition verticale de l'ozone dans l'atmosphère terrestre en deux points de latitude différente à partir d'observations spectrophotométriques d'une éclipse de Lune.

On peut aussi mentionner des mesures d'extinction de l'atmosphère terrestre faites par Elsässer au Jungfraujoch, ainsi que l'étude spectrophotométrique du Gegenschein par Karimov et par Siedentopf et de la lumière du ciel nocturne par Karimov et par Chuvaev.

\section{Spectrophotométrie des raies}

\section{Largeur équivalente et magnitude absolue}

R. M. Petrie a décrit une méthode de détermination des magnitudes absolues des étoiles $\mathrm{B}$ à partir de la mesure de la largeur équivalente de la raie $\mathrm{H} \gamma$. Il faut évidemment tenir compte du type spectral étant donné que la largeur équivalente d'une raie de Balmer dépend non seulement de la magnitude absolue mais aussi du type spectral: la différence entre les types Bo et B 9 est assez grande pour amener une dispersion notable des résultats.

\section{Etoiles des premiers types}

Oke a fait l'étude de 8 étoiles $O$ avec grande dispersion, entre 3300 et $4900 \AA$ et a déterminé les largeurs équivalents de toutes les raies d'absorption mesurables.

Miss Underhill a étudié la variation de la largeur équivalente des raies de l'hydrogène et de l'hélium avec le type spectral pour les étoiles $O$.

La réalisation de spectres composites par superposition de plusieurs spectres de la même étoile (mentionnée dans le rapport de I952), sert à Edimbourg à l'étude des étoiles Br. Elle a permis de mettre en évidence des raies faibles dans le spectre de 7 étoiles $\mathrm{BI}$, avec meilleure détermination du fond continu, et de mesurer dans ces spectres les largeurs équivalentes de 28 raies (R. Wilson).

Aller et $\mathrm{O}$. C. Wilson ont fait la spectrophotométrie des raies des étoiles centrales de quatre nébuleuses planétaires.

\section{Etoiles de types avancés}

Les géantes de type avancé ont été l'objet d'études de la part de McKellar et de Schopp. Buscombe a mesuré les largeurs équivalentes dans le spectre d'étoiles carbonées froides.

\section{Naines blanches}

Les contours de raies des naines blanches sont déterminés par Greenstein au Mont Palomar à l'aide du spectrographe coudé du télescope de 200 pouces qui permet d'atteindre la magnitude $\mathrm{I}_{4}$ avec une dispersion de $38 \AA / \mathrm{mm}$. Les naines blanches 'à spectre continu ' présentent en réalité de très larges raies d'hydrogène. Jusqu'ici on n'observe les raies de l'hélium que dans trois naines blanches.

\section{Novae}

Larsson-Leander a fait l'étude spectrophotométrique des intensités et des contours des bandes d'émission et des raies d'absorption dans le spectre de Nova DK Lacertae et McLaughlin est revenu sur l'interprétation du spectre d'absorption de Nova Herculis. 


\section{Shell-stars, étoiles à raies d'émission}

Des recherches sur lesquelles il est difficile de donner des détails ont été faites sur $\gamma$ Cas (Burbidges), $\zeta$ Tauri (M. Hack), 48 Librae (Underhill), HD I75863 (Taffara), sur diverses étoiles Be (Burbidges) et P Cygni (Miyamoto).

\section{Etoiles variables}

Des études spectrophotométriques sont poursuivies sur les étoiles doubles du type $\beta \mathrm{CMa}$ et sur certaines binaires spectroscopiques telles que $\epsilon$ Aur (Struve), sur $\zeta$ Aur (McKellar et R. M. Petrie), sur RY Scu et AG Peg (Tcheng Mao-Lin et M. Bloch).

De nombreuses références seront contenues dans le Compte-Rendu du Colloque sur les étoiles variables tenu à Pulkovo et à Leningrad à l'occasion de l'inauguration du nouvel observatoire de Pulkovo.

\section{Nébuleuses, matière interstellaire}

Liller et Aller ont mesuré par spectrophotométrie photoélectrique les intensités des raies $N_{1}, N_{2}$ et $H \beta$ dans I2 nébuleuses planétaires brillantes et évalué les brillances absolues par unité de surface. MacRae et Stock ont fait des recherches analogues.

H. M. Johnson a poursuivi et étendu le travail de Struve et Elvey sur les régions galactiques où se manifeste une émission, au voisinage de groupes d'étoiles $O$.

E. M. et G. R. Burbidge ont mesuré l'intensité des raies interstellaires dans le spectre de huit étoiles des premiers types.

\section{Etoiles de la population II}

L. Gratton a fait une comparaison spectrophotométrique entre les géantes $\mathrm{K}$ à grande et à faible vitesse en vue de rechercher des variations d'abondance à partir des courbes de croissance.

W. Iwanowska recherche des différences possibles de composition chimique entre les étoiles appartenant aux divers sous-systèmes.

Au spectrographe coudé du télescope de 200 pouces on fait le spectre des géantes rouges brillantes dans deux amas globulaires. On y étudie aussi les sous-naines à grande vitesse des premiers types: il né semble pas y avoir de grande différence dans les contours des raies de l'hydrogène pour les types $\mathrm{B} 2$ et postérieurs des deux populations I et II (Greenstein).

Greenstein et Aller font l'étude des sous-naines des types $F$ et $G$.

\section{Recherches diverses}

Aux recherches plus générales qui précèdent il faut ajouter de nombreux travaux concernant des étoiles individuelles, émission $\mathrm{H}$ et $\mathrm{K}$ dans les spectres de $\xi$ Boo $\mathrm{A}$ et 70 Oph A (Labs), courbes de croissance révisées pour $\alpha$ Per et $\epsilon$ Aur (Wright), composante secondaire de Capella (Wright), spectre de la radio-source de Cassiopeia (Minkowski et Aller), $\delta$ Scuti (M. Hack), etc.

\section{Classifications stellaires}

Un certain nombre de recherches spectrophotométriques sur le fond continu et sur les raies ont eu pour objet l'amélioration des procédés de classification stellaire.

Des procédés nouveaux ont été développés permettant de classifier les étoiles des premiers types à partir de deux paramètres physiquement bien définis et mesurables, l'un d'eux étant la discontinuité de Balmer $D$ et l'autre, soit une longueur d'onde $\lambda_{1}$ liée à la position de cette discontinuité (Barbier, Chalonge, Divan), soit l'intensité centrale apparente (avec une faible dispersion) d'une des premières raies de Balmer (M. Hack).

Ces méthodes permettent de justifier avec beaucoup de précision et, dans une certaine mesure, d'améliorer la classification de Morgan, Keenan.

L'adjonction aux deux variables $D$ et $\lambda_{1}$ d'une troisième variable, le gradient absolu pour la région bleue-violette (Chalonge, Divan) permet de classer des étoiles qui ne 
trouvaient pas place dans les anciennes classifications (étoiles $\mathrm{A}$ à raies métalliques, sous-naines, RR Lyrae, etc.) (Berger, Fringant).

Sinnerstad étudie de nouveaux critères de luminosité pour les premiers types spectraux.

Les critères employés par l'école suédoise sont développés et utilisés par Westerlund pour des travaux de classification dans la région de Céphée, de la Chevelure de Bérénice.

Mlle Tomasik, collaboratrice de Mlle Iwanowska, a établi des critères spectrophotométriques permettant de reconnaître les étoiles de la population II des types $\mathrm{F}$ et $\mathrm{K}$ dans les spectres à petite dispersion.

\section{Astrophysique expérimentale}

Il semble tout à fait important de mentionner un groupe de travaux qui ont permis de réaliser pour la première fois au laboratoire des conditions physiques semblables à celles qui règnent dans certaines atmosphères stellaires et de contrôler sur les observations expérimentales des théories qui n'avaient jusqu'ici été éprouvées que sur les spectres des corps célestes.

Tous ces travaux ont été effectués par Lochte-Holtgreven et ses collaborateurs (Maecker, Peters, Nissen, Jurgens) du laboratoire de physique expérimentale de l'Université de Kiel.

L'un des dispositifs les plus efficaces utilisés est l'arc de Maecker, produit dans l'axe d'un tube sur les parois internes duquel coule un rapide courant d'eau (tourbillonnaire) laissant juste libre l'axe du tube. L'arc ainsi violemment refroidi, développe des températures extrêmement élevées, dépassant $12000^{\circ}$ et la pression du gaz (mélange d'H et $\mathrm{O}$ du à la dissociation de l'eau) peut atteindre des valeurs très grandes.

L'étude spectrophotométrique du rayonnement émis a permis en particulier d'effectuer des recherches sur l'élargissement des raies de Balmer par effet Stark, et de mettre en évidence le spectre de l'ion négatif hydrogène. Ce dernier spectre avait d'ailleurs pu être observé plus simplement encore sur la lumière de décharges condensées dans l'hydrogène contenu dans un tube capillaire.

\section{Remarques Générales}

L'évolution des recherches de spectrophotométrie stellaire subit actuellement l'influence des progrès réalisés dans la construction de détecteurs photoélectriques de grande sensibilité (photomultiplicateurs) et dans celle de filtres permettant d'isoler une bande donnée du spectre.

Avec ces deux accessoires fondamentaux il est possible de construire des photomètres photoélectriques à filtres, utilisables pour les études stellaires: les résultats de la photométrie stellaire en plusieurs couleurs ainsi obtenus sont précis, pratiquement instantanés et la sensibilité de l'instrument est assez grande pour que les mesures puissent atteindre des étoiles faibles.

Ces importants avantages poussent un nombre croissant d'observateurs à employer ces nouvelles méthodes de photométrie en plusieurs couleurs, au lieu des anciennes méthodes de spectrophotométrie photographique qui ne conduisent, elles, aux résultats, qu'après une longue et fastidieuse série de réductions. Mais les données brutes de cette photométrie sont d'une nature très différente de celles que fournirait la spectrophotométrie et l'on fait en ce moment des efforts pour pouvoir en déduire des informations équivalentes: par exemple, Johnson et Morgan ont établi, dans leur photométrie à trois couleurs, des critères photométriques pour la classification des spectres, équivalents aux critères purement spectroscopiques antérieurement usités.

De toute façon la photométrie fournit des résultats empiriques dont la signification physique est mal définie et qui doivent être étalonnés à partir de données spectrophotométriques préalablement obtenues sur des étoiles de types analogues. C'est ainsi qu'à partir des excellentes observations de photométrie en six couleurs de Stebbins et Whitford, Mlle Divan a pu déduire avec une très bonne précision, la loi d'absorption de la 
lumière par la matière interstellaire mais la méthode employée n'a pu être établie qu'en faisant appel à une étude spectrophotométrique de Hall et à des corrections déduites de mesures spectrophotométriques des discontinuités de Balmer.

On voit donc que l'interprétation et l'exploitation des résultats de la photométrie en plusieurs couleurs exigent que des études spectrophotométriques préalables soient faites des propriétés des spectres (et tout spécialement des spectres continus) des étoiles des divers types (ce mot étant entendu dans un sens beaucoup plus large que d'habitude et désignant toutes les espèces d'étoiles des diverses populations).

La photométrie permettra ensuite de rechercher et de reconnaître ces types d'étoiles dans des régions lointaines de la Galaxie beaucoup plus rapidement que ne pourrait le faire la spectrophotométrie.

Ainsi la photométrie en plusieurs couleurs peut être considérée comme un auxiliaire et un prolongement simplifié de la spectrophotométrie. On ne peut pas attendre d'elle tout ce que l'on attend de la spectrophotométrie: la connaissance de l'intensité globale de quelques groupes de radiations d'un spectre constitue évidemment une source d'informations beaucoup moins riche que la connaissance des intensités de toutes les radiations monochromatiques de ce spectre.

\title{
VaEUX
}

Divers membres de la commission demandent précisément que les données spectrophotométriques définissant les spectres continus (et sur l'importance desquelles l'attention a été attirée au paragraphe précédent), soient déterminées pour toutes les espèces d'étoiles.

On peut dire qu'une grande partie de ce travail est en voie d'exécution à l'Institut d'Astrophysique de Paris mais il serait souhaitable que, conformément à un vœu émis par cette commission lors du Congrès de Stockholm, en I938, les mêmes déterminations soient faites, pour les étoiles de l'hémisphère austral, afin de définir dans tout le ciel des étoiles de référence de valeur comparable pour l'étude des étoiles plus faibles.

\author{
D. Chalonge \\ Président de la Commission
}

\section{6a. SUB-COMMISSION ON' LINE INTENSITY STANDARDS}

This sub-commission was organized in 1948 in an attempt to set up a system of stellar line-intensities that could be reproduced at any observatory whree spectra of moderate or high dispersion could be obtained. Since the intensities of spectral lines are very important in the study of stellar atmospheres and since there were often large differences in the intensities of the same lines measured at different observatories, it seemed desirable that a sub-commission be formed to investigate this problem. First reports were presented at the Rome meetings of the International Astronomical Union in 1952, and a list of stars that might be suitable for inter-observatory comparisons was given (r). Of the stars on that list, only $\lambda$ Piscium now seems unsuitable because the lines appear broad and shallow on high-dispersion spectrograms.

During the past two years the principal work of the sub-commission has been (I) to obtain spectra of the proposed line-intensity-standard stars and to make measurements of equivalent widths for inter-observatory comparisons; and (2) to make a further study of the relation between measured equivalent width and the dispersion and resolving power employed.

G. Righini and his co-workers $(2,3)$ at Asiago Observatory have published profiles and equivalent-width measurements of lines in the spectra of Sirius and Procyon, the 
dispersions being $40 \AA / \mathrm{mm}$. (camera III) and $\mathrm{I}_{3} \AA / \mathrm{mm}$. (camera IV) in each case. They have compared their results with other published data as follows:

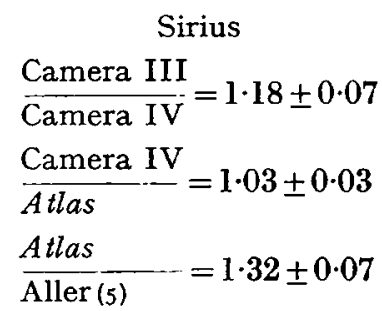

\author{
Procyon \\ $\frac{\text { Camera III }}{\text { Camera IV }}=1 \cdot 00 \pm 0 \cdot 06$ \\ $\frac{\text { Atlas (4) }}{\text { Camera IV }}=1 \cdot 10 \pm 0 \cdot 04$ \\ $\frac{\text { Wright (6) }}{\text { Camera IV }}=0 \cdot 86 \pm 0 \cdot 04$
}

Further studies of high-dispersion spectra of Procyon obtained at the Mount Wilson and Dominion Astrophysical Observatories are being made by M. H. Wrubel at Indiana University and a comparison of these data should be available within a few months.

Spectra of most of the stars on the list of proposed standards have been obtained at the Dominion Astrophysical Observatory with a Bausch and Lomb 30,000 lines/inch grating in a Littrow mounting which gives a dispersion of $3 \cdot 2 \AA / \mathrm{mm}$. In co-operation with Greenstein, who has obtained Mount Wilson spectra of a number of the stars, a preliminary comparison of equivalent widths has been made in the region $\lambda \lambda 4000-4500$. A check on the calibration devices used at Mount Wilson and Victoria was made in 1952 by Wrubel with the co-operation of Greenstein and Wright. Calibration spectra taken of the Mount Wilson wedge and step-slit were photographed on the same plates as a spectrum of the Victoria step-sector calibration. Analysis with the Victoria microphotometer gave almost identical characteristic curves for all three calibrations, any differences being very small and well within the errors of measurement.

Mount Wilson spectra of I5 Vulpeculae, A5, which has numerous lines and a welldefined continuum, were measured by G. R. Miczaika and equivalent widths were compared with Victoria measures by Wright and E. K. Lee. For I24 lines in the region $\lambda \lambda 4000-4485$ having equivalent widths greater than $50 \mathrm{~m} \AA$, the Mount Wilson values are $2.5 \%$ larger, on the average, than the Victoria data. An intensity tracing of $\sigma$ Bootis, Fo, made at Mount Wilson Observatory, was measured at Victoria. The lines are stronger and more numerous than in I5 Vulpeculae, but the continuum is fairly well defined. In the region $\lambda \lambda 4370-4450$, the continua for Mount Wilson and Victoria spectra were drawn at the same level as nearly as possible; for 26 lines the Mount Wilson equivalent widths were found to be $6 \%$ smaller than the Victoria values. In the region $\lambda \lambda 4000-4075$, where the continuum is more difficult to determine, the reductions were made quite independently and, for $2 \mathrm{I}$ lines, the Mount Wilson data were $12.5 \%$ smaller than the Victoria values.

For the late-type stars, $\lambda$ Serpentis, Go, and $\mu$ Herculis, $G_{5}$, where the continuum is difficult to determine in the region $\lambda \lambda 4000-4500$, intensity tracings were measured at Victoria and sent to Greenstein for comparison with his spectra of the same stars. In this region, measures of $5^{\circ}$ lines indicated that the Mount Wilson equivalent widths were smaller than the Victoria values by $3 \mathrm{I} \%$ for $\lambda$ Serpentis and $18 \%$ for $\mu$ Herculis. Greenstein considers that the continuum was drawn rather too high on the Victoria spectra and that the wings of strong lines were made too extensive. Greenstein first measures each line as a triangular profile and then adds $6 \%$ to the equivalent width on the assumption that the true profile is Gaussian; he remarks: 'I do not think it possible to force wings on lines because if one does so, one is inventing a continuum which cannot be observed because of the continuous overlapping of the wings.' Wright, on the other hand, superposes the profiles of the lines least affected by blends, draws a series of mean profiles, which are measured with the planimeter, and interpolates the equivalent widths of other lines, making allowance for blending effects as well as possible; wings are included in the measurements if they are noted consistently for the profiles of the unblended lines. The above results indicate that the calibration devices at the Mount Wilson and 
Dominion Astrophysical Observatories give similar and, presumably, accurate characteristic curves and that equivalent widths measured at these observatories can be considered nearly the same, within the probable errors of measurement, for lines in stellar spectra where the continuum is well defined. However, for complex spectra where the continuum is uncertain and where the extent of the wings of strong lines is a matter of judgment, large differences in the measured equivalent widths are found.

At least four papers that discuss the effect of resolving power and dispersion on equivalent-width measurements have appeared since the last report. Pecker and van Regemorter ( 7 ) derived solar spectra corresponding to different resolving powers by averaging the intensity profile of the Utrecht Photometric Atlas of the Solar Spectrum (8) over wave-lengths of one-quarter to two angstroms and showed that, when the presence of neighbouring lines is known, equivalent widths of the components are not affected appreciably by resolving power. However, in a discussion of measures of solar lines by Houtgast and Gathier (9) Pecker and van Regemorter note that when the same resolving power but lower dispersion is used, faint lines may become indistinguishable from grains in the plate. Their presence may then be detected either as a lowering of the continuum, for separated lines, and therefore as an observed decrease in the equivalent width of other lines, or as an increase in the measured equivalent width of a line of which the weak line is then a component.

Cayrel (ro) discussed sources of error in spectrophotometry as a result of using too wide an analysing slit for the microphotometer. Near the wing of a line, the observed integrated intensity is then the mean of a large range of intensities in the line and since the microphotometer takes the mean of the transmissions rather than of the intensities, it is found that the wings of absorption lines are measured too strong and the equivalent widths too large. This effect is pronounced as the dispersion is varied since, for the same width of microphotometer slit, a larger range in wave-length is covered on plates of lower dispersion. In a second paper, Cayrel (rr) noted other secondary effects produced by the microphotometer: the focus may be poor because the receiver is most sensitive to infrared radiation, whereas focusing is done visually, and, in addition, the thickness of the photographic emulsion is not negligible and therefore a point focus cannot be obtained. Both effects tend to increase the measured absorption in a spectrum line. It may be noted that a test of the above effect was made with the Victoria microphotometer, which uses a photocell sensitive to the infra-red, by inserting a filter which permitted only blue light to reach the receiver, and by using a slit which was only one-half the usual width. Intensity tracings of the spectrum of Procyon, which has very sharp absorption lines, were obtained in the usual manner and also with the above-mentioned changes. No differences could be detected for the lines of Procyon but, for a plate showing very fine emission comparison lines, the lines appeared slightly sharper when the filter and narrow slit were used.

Deutsch (x2) has made a theoretical investigation of the effect of increasing the width of the microphotometer analysing slit and agrees with Cayrel that the measured equivalent width of an absorption line may be expected to increase as the linear dispersion decreases.

The above effect was studied empirically (13) using spectra of $\alpha$ Cygni taken with various dispersions at the Dominion Astrophysical Observatory. The results have now been extended to lower dispersions and numerous high-dispersion grating plates have been measured in order to derive grating equivalent widths of lines in the spectrum of $\alpha$ Cygni from $\lambda 4000$ to $\lambda 4500$. In Table $x$ are listed the average percentage differences between the adopted grating equivalent widths and similar measures made on spectra ranging in dispersion from $5 \mathrm{I}$ to $5 \AA / \mathrm{mm}$. at $\mathrm{H} \gamma$. Also included in the table are similar comparisons with other available data and also with the results for the various Victoria gratings. The writer would like to thank Dr Su-Shu Huang for making available to him unpublished equivalent widths obtained from Mount Wilson plates taken by Dr O. Struve. In all series of measurements made at Victoria, several intensity tracings were 
superposed in order to eliminate, as much as possible, the effects of plate grains, and highdispersion tracings were used as a guide to detect the presence of possible components. Blends were usually eliminated, but in the case of a few lines, weak components were present and were allowed for as well as possible. On low-dispersion plates (5I and 3 I $\AA / \mathrm{mm}$.) it was found that no trustworthy measures could be made for lines having equivalent widths less than Ioo $\mathrm{m} \AA$; if measures were made on such lines, the results were almost always too large by $25-100 \%$. It should be noted from the table that, in general, equivalent widths derived from grating spectra are lower than those obtained from prismatic spectra of $\alpha$ Cygni, even though allowance has been made for the presence of grating ghosts. A possible reason for this difference could be the presence of general scattered light in the gratings. It is hoped to make measurements in the near future to test this possibility. In view of the relatively large differences in the equivalent widths measured at different observatories, and also in view of the differences between measures of spectra obtained with prisms and with gratings, it would seem safe to conclude that no significant difference has been established between measures of equivalent widths of lines in the spectrum of $\alpha$ Cygni determined from high-dispersion and from low-dispersion plates.

Table r. Line Intensities in the Spectrum of $\alpha$ Cygni, $\lambda \lambda 4000-4540$

\begin{tabular}{|c|c|c|c|c|c|c|}
\hline & Type & Instrument & $\begin{array}{l}\text { Disper- } \\
\text { sion } \\
\text { at } \mathrm{H} \gamma \\
(\AA / \mathrm{mm} .)\end{array}$ & $\begin{array}{l}\text { No. of } \\
\text { plates }\end{array}$ & $\begin{array}{l}\text { No. of } \\
\text { lines }\end{array}$ & $\begin{array}{l}\text { Mean difference } \\
(\%) \text { relative to } \\
\text { average Victoria } \\
\text { grating values }\end{array}$ \\
\hline Victoria & Grating & Wood & $4 \cdot 5$ & 3 & 46 & $+13 \cdot 4 \pm 8 \cdot 6$ \\
\hline Victoria & Grating & BL 84 & $4 \cdot 5$ & 6 & 53 & $-3 \cdot 8 \pm 5 \cdot 8$ \\
\hline Victoria & Grating & BL 82 & $7 \cdot 0$ & 3 & 44 & $+4 \cdot 2 \pm 6 \cdot 4$ \\
\hline Victoria & Grating & BL 169 & $3 \cdot 2$ & $\mathbf{3}$ & $\mathbf{5 2}$ & $-6.8 \pm 6.1$ \\
\hline Victoria & Grating & Mt. W. 71 & $2 \cdot 8$ & 3 & 39 & $-\mathbf{2 \cdot 2} \pm \mathbf{5 \cdot 5}$ \\
\hline Victoria & Prism & I S & 51 & 8 & 51 & $+8.9 \pm 12.4$ \\
\hline Victoria & Prism & I $\mathbf{M}$ & 31 & 14 & 54 & $+7 \cdot 3 \pm 8.2$ \\
\hline Victoria & Prism & I L & 22 & $\mathbf{3}$ & 34 & $-3 \cdot 7 \pm 12 \cdot 0$ \\
\hline Victoria & Prisms & II L & 11 & 6 & 39 & $+18.4 \pm 12.5$ \\
\hline Victoria & Prisms & III L & 5 & 3 & 32 & $+16 \cdot 9 \pm 9 \cdot 7$ \\
\hline Hiltner-Williams Atlas $^{a}$ & Prisms & - & 3 & $\mathbf{l}$ & 61 & $+14.4 \pm 8.5$ \\
\hline Buscombe $^{b}$ & Grating & 一 & $2 \cdot 8$ & 3 & 48 & $-9 \cdot 4 \pm 7 \cdot 2$ \\
\hline Huang ${ }^{c}$ & Grating & 一 & $2 \cdot 8$ & - & 48 & $-13 \cdot 3 \pm 6 \cdot 7$ \\
\hline
\end{tabular}

- W. A. Hiltner and R. C. Williams, Photometric Atlas of Stellar Spectra.

b W. Buscombe, $A p$. J. rr4, 73, I95I.

c S. S. Huang and O. Struve, $A$ P. J. 121, 84, 1955.

Finally, the importance of further development of the method of scanning the spectra of bright stars directly with a photocell behind a narrow slit must be emphasized since the method is fundamental in itself and would also provide a most valuable check on the present photographic calibration techniques. Greenstein remarks that Code and Whitford now have such an instrument at the Mount Wilson Observatory but they use 'rather low resolution', and he urges more effort in this field.

KENNETH O. WRIGHT

President of the Sub-commission

REFERENCES

(I) Trans. I.A.U. 8, 564 and 589 , I954.

(2) G. de Strobel, Contr. Obs. Astrophys. Asiago, no. 3I, 1953.

(3) S. Taffara, Contr. Obs. Astrophys. Asiago, no. 32, 1953.

(4) W. A. Hiltner and R. C. Williams, Photometric Atlas of Stellar Spectra (University of Michigan Press, Ann Arbor, 1946). 
(5) L. H. Aller, $A p . J .96,324,1942$.

(6) K. O. Wright, P. Dom. Ap. Obs. 8, I, I948.

(7) J. C. Pecker and H. van Regemorter, Ann. Astrophys. 15, 364, 1952.

(8) M. Minnaert, G. F. W. Mulders and J. Houtgast, A Photometric Atlas of the Solar Spectrum (Schnabel, Amsterdam, I940).

(9) J. Houtgast and P. Gathier, Trans. I.A.U. 8, 568, 1954.

(10) R. Cayrel, Ann. Astrophys. 16, 129, 1953.

(I I) R. Cayrel, Ann. Astrophys. 16, 466, 1953.

(12) A. J. Deutsch, J. Opt. Soc. Amer. 44, 492, 1954.

(13) K. O. Wright, Trans. I.A.U. 8, 592, 1954.

\section{6b. SUB-COMMISSION ON THE THEORY OF STELLAR ATMOSPHERES}

\section{Introduction: Textbooks}

Considerable parts of our subject are covered by recent books which also contain extensive references to other literature:

L. H. Aller, Astrophysics (2 Vols.: New York, 1953/54).

S. Chandrasekhar, Radiative Transfer (Oxford, 1950).

V. Kourganoff, Basic Methods in Transfer Problems (Oxford, 1952).

A. Unsöld, Physik der Sternatmosphären (2nd ed.: Berlin-Göttingen-Heidelberg, 1955).

R. v. d. R. Woolley and D. W. N. Stibbs, The Outer Layers of a Star (Oxford, 1953).

V. A. Ambartsumian, E. R. Mustel, A. B. Severny and V. V. Sobolev, Theoretical A strophysics

(in Russian: Moscow, 1952).

We shall therefore restrict ourselves here to emphasizing some essential viewpoints without giving complete references.

\section{Radiative equilibrium}

\section{Models of stellar atmospheres}

'How do the temperature $T$, the electron pressure $P_{e}$, the gas pressure $P_{g}$ depend upon the geometrical depth $t$, the optical depth $\tau_{\nu}$ for some frequency $v$ or $\bar{\tau}$ for the total radiation in a stellar atmosphere?'

Until some years ago the connexion between $T$ and $\bar{\tau}$ was mostly calculated under the assumption of 'grey' radiative equilibrium. Practical work has shown that such models are not much better than taking constant average values of $T$ and $P_{e}$. In earlytype atmospheres the huge jump of $\kappa_{\nu}$ at the Lyman limit of hydrogen and in later types the Fraunhofer lines must be taken into account in calculating $T(\bar{\tau})$.

For dealing with 'non-grey' problems of radiative equilibrium the following methods are available:

(a) $\Lambda$-iteration (B. Strömgren, A. Unsöld), converging well for small $\tau$ but not for large ones.

(b) Flux iteration (A. Unsöld, I95I), having just the reverse properties.

(c) A 'combined iteration' procedure having the advantages of $(a)$ and $(b)$ without their disadvantages ( $x$ ).

Sometimes also simple trial and error methods can be used with advantage.

Tables and graphs on ionization, absorption coefficients, etc., have been calculated at Kiel and recently also at Kyoto Observatory. Methodically interesting attempts of applying electronic computing to model stellar atmospheres have been made by J. McDonald at Toronto.

\section{Convective zones}

Long ago L. Biermann pointed out that within the hydrogen convection zone of the Sun, for example, the energy is transported by convection. The problem of how a 
convective zone should be fitted into a radiative one requires us to deal with the transfer of energy by convection and radiation. E. Vitense (2) has investigated the hydrogen convection zone of the Sun, using - as far as hydrodynamics is concerned-Prandtl's 'Mischungsweg' theory. Concerning the adiabatic temperature gradients A. Underhill proposed that the entropy of radiation should not be forgotten. It can be shown, however, that in all cases where energy is transported mainly by convection, the entropy of radiation is quite unimportant compared with that of matter. In the outer layers of stellar atmospheres the motions originating in a convective zone lead to what has been termed turbulence, shock waves, spicules, magnetohydrodynamic waves, etc. The heating of the corona is most probably connected with these phenomena. Our knowledge of the basic physical processes is still very limited. Semi-empirical investigations on the solar chromosphere under modern viewpoints have been published by L. Woltjer(3) and E. Böhm-Vitense (4); reference should be made also to the work of R. N. Thomas(5) and his collaborators.

The importance of the temperature inhomogenities produced by convection in the Sun (and, presumably, late-type stars) has been investigated by C. de Jager (6) (Balmer lines) and K. H. Böhm (7) (centre-limb variation of metallic lines). Also the solar 'limb effect' must be mentioned in this connexion.

\section{Origin of Fraunhofer lines}

With regard to radiative transfer in Fraunhofer lines Savedoff, Labs, Miyamoto and others have made extensive calculations on non-coherent scattering. Comparing the theoretical results with observation it should be kept in mind that it is doubtful whether the 'models' used in these very complicated calculations give a sufficiently close approximation to actual stellar atmospheres.

W. Priester (8) investigated 'anomalous multiplets' (giving some bright lines in T Tauri and other peculiar stars, according to Thackeray owing to energy transfer from other atoms) in the Sun and other normal stars. No effect was found. All the available evidence indicates that for normal atmospheres the lines follow fairly closely the scheme of local thermodynamic equilibrium or true absorption.

The cinetic theory of non-equilibrium states is beset with pitfalls. One shculd avoid using the term 'deviation from thermodynamic equilibrium' just to indicate a certain degree of ignorance. Good work has been done for many years on the extreme cases of planetary nebulae and interstellar matter (9). Concerning ionization in the solar corona, there are still quantitative difficulties (ro). K. H. Böhm(ri) investigated deviations from the Saha formula in the outermost layers of the solar atmosphere due to differences between the densities of the actual field of radiation and the Planck field for the local temperature. They are important in connexion with the centre-limb variation of Fraunhofer lines.

The calculation of line contours-following the scheme of local thermodynamic equilibrium - can be done and is done more and more by straightforward numerical quadrature. P. ten Bruggencate reports favourably on using electronic computing machines.

For weak lines or the wings of strong lines the method of weight functions has been used frequently. For stronger absorption it can be generalized, either connecting it directly with the usual theory of the curve of growth, or following generalized and somewhat more accurate (but also more complicated) procedures indicated by J. C. Pecker (I2) and V. Weidemann ( 13 ).

As regards the atomic aspects of our problem, the importance of getting more and better $f$-values cannot be overemphasized. The tables by D. R. Bates and A. Damgaard ( ${ }_{4}$ ) are most useful. Experimental methods applying the electric furnace, the electric arc, atomic beams in absorption or fluorescence or shock tubes are being developed in various laboratories. 'Astrophysical' $f$-values so far have large accidental and systematic errors; they might be improved by paying more attention to the physical characteristics of the source. 
Damping constants due to collisions with hydrogen atoms can be calculated now fairly accurately by evaluating the $\overline{r^{2}}$-matrices, according to a proposition made by Bates and Damgaard. A comparison between quantum mechanical theory and observation for laboratory measurements using rare gases and for strong lines of the solar spectrum has been made by $V$. Weidemann and A. Unsöld (15).

As regards the broadening of hydrogen lines, laboratory experiments using a hightemperature arc by $G$. Jürgens (r6) and others working with $W$. Lochte-Holtgreven at Kiel tend to confirm the Holtsmark theory and the Inglis-Teller formula. Recent measurements (unpublished) made at Ann Arbor using a shock tube for producing high temperatures, on the other hand, seem to lead to contradictions with the Holtsmark theory.

Also the astrophysical aspect of the matter is still confused. C. de Jager ( $r$ ), working on the hydrogen lines of the Sun and their centre-limb variation, first introduced empirical corrections to the Holtsmark theory, which however for corresponding Balmer and Paschen lines are theoretically inconsistent. Later he tried to improve the model of the solar atmosphere by paying attention to the temperature inhomogenities produced by the convection (granulation). As regards hotter stars, where convection is rather unimportant, G. Traving (r8) and K. Hunger (2x) in their very detailed studies of $\tau$ Sco and $\alpha$ Lyr obtain quite reasonable agreement between theory and observation. A. Underhill's recent work on $\mathrm{H} \alpha$ in $\iota$ Her and $\epsilon$ Per, on the other hand, indicates disagreement between theory and observation. An important point is that one must determine very carefully the parameters $T_{e}$ and $g$, i.e. the 'model' for every star individually.

One of the chief aims and-at the same time-tools of the theory of stellar atmospheres is the determination of their chemical composition. Passing beyond the stage of a rough analysis (Grobanalyse), using constant average values for temperature and pressure in a stellar atmosphere, the procedures become very intricate if a real gain in accuracy is aimed at. Simple estimates, using the Boltzmann and Saha formulae, indicate that real progress beyond the 'Grobanalyse' requires non-grey models whose parameters, being $T_{e}, g$ and the essential features of the composition, have been determined with great care in the course of the analysis itself.

Considering critically the interesting work by W. J. Claas (rg) on the Sun, it turns out that the changes in the abundance of many elements produced by passing from his solar model to more recent (and presumably better) ones are about as large as between the old rough analysis and his latest work!

Similarly work by A. Underhill as well as L. Neven and C. de Jager (20) seemed to lead to a considerably smaller abundance ratio of $\mathrm{He}: \mathrm{H}$ than the previous rough analysis of $\tau$ Sco and other stars. Recently, however, G. Traving (18) showed that also spectral analysis using a detailed model leads to $\mathrm{He}: \mathrm{H}=\mathrm{I}: 5$, if $T_{e}$ and $g$ are determined correctly for the star individually by a complete analysis of the whole spectrum.

Spectral work reaching presumably the maximum degree of accuracy and completeness now possible has been done recently on $\tau$ Sco, $\alpha$ Lyr and the Sun by Traving(r8), Hunger (21), and Weidemann ( (3). $^{2}$.

During the last years it became increasingly evident that not all stellar atmospheres have the same chemical composition. We should mention the work of $L$. $H$. Aller and A. D. Thackeray on He-stars, of R. Wildt, M. Schwarzschild, N. Roman, P. Wellmann and others on high-velocity and population II stars, of McKellar on the ratio of the isotopes $\mathrm{C}^{12}$ and $\mathrm{C}^{13}$. The connexion between quantitative analysis of stellar spectra on the one hand, stellar astronomy and evolution on the other hand now offers some of the most exciting problems in astrophysical research.

A. UNSÖLD

President of the Sub-commission 
(1) K. H. Böhm, Z. Ap. 34, 182, I954 and 36, 295, 1955.

(2) E. Vitense, $Z . A p .32, \mathrm{I} 35, \mathrm{I} 953$.

(3) L. Woltjer, Bull. Astr. Insts. Netherlands, 12, I65, 1954.

(4) E. Böhm-Vitense, Z. Ap. 36, 145, 1955.

(5) R. N. Thomas, $A p . J$. 1955.

(6) C. de Jager, Nature, 173, 680, 1954.

(7) K. H. Böhm, $Z . A p .35$, r 79, 1954 .

(8) W. Priester, $Z$. Ap. 36, 230, 1955.

(9) See K. Wurm, Planetarische Nebel (Berlin, I95I).

(Io) See H. C. van de Hulst in The Sun, ed. G. Kuiper (Chicago Univ. Press, I953).

(I I) K. H. Böhm, Z. Ap. 35, I79, I954.

(12) J. C. Pecker, Ann. Astrophys. 14, 383, I95I.

(13) V. Weidemann, $Z$. Ap. 36, rox, 1955.

(r4) D. R. Bates and A. Damgaard, Phil. Trans. Roy. Soc. A, 242, Ior, 1949.

(15) .V. Weidemann and A. Unsöld, Vistas in Astronomy (ed. A. Beer), Vol. I, Sect. 4; London and New York, 1955.

(16) G. Jürgens, Z. Phys. 134, 21, I952.

(17) C. de Jager, Rech. Astr. Utrecht, I3, I, 1952.

(18) G. Traving, $Z . A p \cdot$ 36, r, 1955 .

(19) W. J. Claas, Rech. Astr. Utrecht, r2, I, I95I.

(20) L. Neven and C. de Jager, Bull. Astr. Insts Netherlands, 12, 103, 1954.

(2I) K. Hunger, $Z . A p \cdot 3^{6}, 42$, I955.

\section{BIBLIOGRAPHY}

Les processus nucléaires dans les astres, Coll. Int. d'Astrophys. Liège, 1953. $=$ Mem. $\left(3^{\circ}\right)$ Soc. Roy. Sc. Liège (4) xIV, I ; Louvain, 1954.

Stellar atmospheres, Nat. Sc. Found. Coll. Univ. Indiana, I954.

Canavaggia, R. et J. C. Pecker, $A n n . A p .15,260$, 1952 et 16, 47, 1953. (Yellow giants.)

Michard, R. Ann. Ap. 16, 217 , 1953. (Sunspots, etc.)

Mineur, H. et R. Peyturaux, $A n n . A p$. 15, 383, 1952. (Solar source function.)

Pecker, C. Ann. Ap. 16, 321, 1952. (Convective zones.)

Peyturaux, R. Ann. Ap. 15, 302, 1952. (Continuous spectrum of the Sun.)

Pecker, J. C. Ann. Ap. 13, 294, 319 et 433, 1950; 14, II 5, I95 I (Stellar atmospheres); 14, 383, 195I. (Weight functions for strong lines.)

Schatzman, E. Acad. Roy. Belg. Sc. 39, 960, I953 et 40, 139, 1954. (Granulation.)

Compte rendu de la séance. 2 septembre 1955

Président: Dr D. Chalonge.

SECRÉtaIRE: Dr B. Westerlund.

Le Président commence par présenter quelques additions à son rapport (le rapport est divisé comme le rapport principal).

Rapport complémentaire:

\section{Spectrophotométrie Photó́lectrique}

W. L. Wilcock a construit un spectrophotomètre électrique à deux photomultiplicateurs, permettant de corriger automatiquement les variations de 'seeing' et destiné plus spécialement à l'étude des contours de raies.

A l'observatoire de Crimée, V. B. Nikonov étudie un spectrophotomètre à deux photomultiplicateurs pour la spectrophotométrie stellaire. 


\section{SOURCES DE COMPaRAison}

Des renseignements nouveaux ont été obtenus concernant l'emploi du cratère positif de l'arc au carbone et celui de la lampe à ruban de tungstène. Ils sont développés dans un exposé qu'à présenté le Prof. Kienle au cours de la séance (résumé ci-dessous).

Un laboratoire central pour les études de spectrophotométrie absolue est crée à Heidelberg sur l'initiative du Prof. Kienle. L'organisation de ce laboratoire a fait également l'objet d'une communication (résumé ci-dessous).

M. Minnaert et M. Chalonge expriment au Prof. Kienle la grande reconnaissance des membres de la commission pour sa remarquable et importante initiative et demandent que celle-ci soit portée à la connaissance du Congrès tout entier.

\section{SPECTROPHOTOMÉTRIE DES SPECTRES CONTINUES}

\section{Spectrophotométrie stellaire absolue}

O. A. Melnikov a appliqué à la détermination du zéro de l'échelle des gradients absolus une méthode qu'il avait proposée en I950. Les valeurs obtenues pour les gradients des étoiles Ao dans le domaine visible ont l'ordre de grandeur voulu.

\section{Nébuleuses, matière interstellaire}

B. Westerlund a étudié le rougissement dans la région des Pléiades. L'absorption varie beaucoup d'un point à l'autre.

$\mathrm{Au}$ cours des recherches spectrophotométriques dans les régions de Coma Berenices et des Pléiades N. N. Gorochova a examiné aussi l'absorption sélective dans les Pléiades.

\section{SPECTROPHOTOMÉTRIE DES RAIES}

\section{Shell-stars, étoiles à raies d'émission}

G. Righini, G. de Strobel, G. Godoli, G. Mannino et S. Taffara ont étudié I5 étoiles Be et 3 étoiles $B$.

\section{Etoiles variables}

G. Cayrel-de Strobel a mis en évidence que pour deux étoiles à éclipses, Algol et RZ Cas, la profondeur des premières raies de Balmer augmente au voisinage du minimum primaire, contrairement à ce que l'on pouvait attendre. Ce phénomène pourrait s'expliquer par l'existence d'une atmosphère relativement étendue autour de la composante sombre ou de l'ensemble des deux étoiles.

\section{VGUX}

Conformément au vœu émis par quelques membres de la Commission les données spectrophotométriques définissant les spectres continus stellaires commencent à être publiées (Journal des Observateurs).

M. Kourganoff félicite M. Chalonge pour son rapport.

Le Dr Greenstein demande à M. Chalonge s'il peut donner quelques renseignements sur les résultats nouveaux obtenus à l'Institut d'Astrophysique sur les spectres continus stellaires. M. Chalonge fait un exposé, dont le résumé est donné ci-dessous.

Mme Cayrel-de Strobel signale les résultats qu'elle a obtenus sur Algol et RZ Cas (mentionnés dans le rapport complémentaire).

Mlle Underhill demande si on ne pourrait pas discuter des méthodes employées pour 
tracer les fonds continus des spectres stellaires des types avancés. Après un court échange de vues les membres de la Commission tombent d'accord pour émettre le vœu que cette question d'un intérêt fondamental et dont l'examen demanderait un temps assez long soit reportée au Congres prochain.

\section{RÉSumé de la Communication faite PaR H. Kienle}

\section{Standard light sources for use in spectrophotometry}

The primary standard for fixing the zero point of the stellar temperature scale is the Black Body realized by an electric furnace with carbon or tungsten tube(r). The carbon tube can be operated at temperatures not much higher than $2300^{\circ} \mathrm{K}$. whilst with a tungsten tube one may reach $3000^{\circ} \mathrm{K}$. A temperature of $3000^{\circ} \mathrm{K}$. is not very high as compared with stellar temperatures and even to realize Black-Body radiation of such moderate temperature within about $\pm 5^{\circ}$ demands a great amount of instrumental equipment and control. Therefore it is not to be recommended to use the Black Body itself for direct comparisons with stars but secondary light sources which have been calibrated by comparison with the Black Body.

Such secondary light sources are: the tungsten strip lamp, the positive crater of carbon arc, the xenon high-pressure arc, the hydrogen discharge, the 'poudre-fluorescente' disc.

(a) Tungsten strip lamps(2) give a real continuous spectrum without any lines over the whole range of wave-lengths corresponding to colour temperatures of about $2500^{\circ} \mathrm{K}$., very low as compared with stars. The apparent colour temperature may be transformed to values as high as $10,000^{\circ} \mathrm{K}$. and even more with the aid of combinations of colour filters, but this method works only for restricted parts of the spectrum and there remain always ondulations in the intensity distribution as it is not possible to get filters with transmission curves varying linearly with $\mathrm{r} / \lambda$. The lamps must be operated at currents of the order of $I_{5}$ amp., and to have the temperature kept constant within $I \%$ demands a precision of current of about $\mathrm{I} \%$. Recent studies of the emissivity of tungsten ribbons by de Vos are very promising as to the possibility of using tungsten strip lamps as standard light sources replacing the real Black Body, it seeming sufficient to measure and control the temperature with a calibrated pyrometer at only one single wave-length.

(b) The Carbon $A r c(3)$ has been proposed as pyrometric standard because of its selfstabilizing at a temperature of about $4000^{\circ} \mathrm{K}$. if operated just below the 'hiss-limit' (Zischgrenze). The radiation of the positive crater is nearly gray, the emissivity falling off only very little towards the ultra-violet, corresponding to a correction of gradient of 0.032 . Recent intercomparisons of standards in Berlin, Heidelberg and Paris have led to the conclusion that the absolute temperature of the crater depends in some degree on the internal structure of electrodes, varying between $3995^{\circ} \mathrm{K}$. (the value given by Euler and by MacPherson for pure 'graphite') and $3845^{\circ} \mathrm{K}$. (the value given by MacPherson for 'carbon'). The best method for fixing the temperature seems to be, as in the case of tungsten lamps, the use of a carefully calibrated pyrometer. The extended bands of $\mathrm{CN}$ of arc spectrum which are superposed to the continuous spectrum of the crater may be suppressed by operating the arc in an atmosphere of $\mathrm{CO}_{2}$. Then the carbon arc may be used over the whole range of spectrum from U.V. to I.R.

(c) The Xenon High-pressure Arc(4) shows a continuous spectrum with only a few sharp emission lines superposed below $6800 \AA$. The intensity distribution corresponds to a colour temperature of about $5600^{\circ} \mathrm{K}$., and is highly independent of working conditions. Recently developed lamps (Osram) with a 'wall-stabilized' arc of ro mm. length consuming only $\mathrm{r} 60$ watts seem most suitable for spectrophotometric use.

(d) The Hydrogen Discharge(s) is distinguished by high intensity of U.v. radiation. There is a real continuous spectrum without any lines below $3700 \AA$ and with nearly zero gradient $\left(T_{c}=\infty\right)$. With even moderate dispersion it is impossible to pick up the continuum between the many emission lines superimposed in the blue to red parts of the spectrum. 
A small lamp with a glowing bubble of some millimetres in diameter and consuming only about 30 watts which is used in a U.V. spectrophotometer of Zeiss has proved to be very suitable for comparison of early type stars.

(e) The 'Poudre Fluorescente' light source proposed by Chalonge(6) is wholly independent of working conditions, the fluorescence spectrum excited by the resonance line of mercury being determined by the nature of the fluorescent substances pressed between quartz plates. As it is necessary to use mixtures of salts for covering the whole range of spectrum by superposition of several continua with different maxima of emission, the intensity distribution of radiation cannot be characterized by a gradient. The apparent colour temperature varies from some $5000^{\circ} \mathrm{K}$. in the red to about $40,000^{\circ} \mathrm{K}$. in blue and U.v. This light source may in future perhaps be used for intercomparison of standards all over the world by exchange of a set of plates of identical composition.

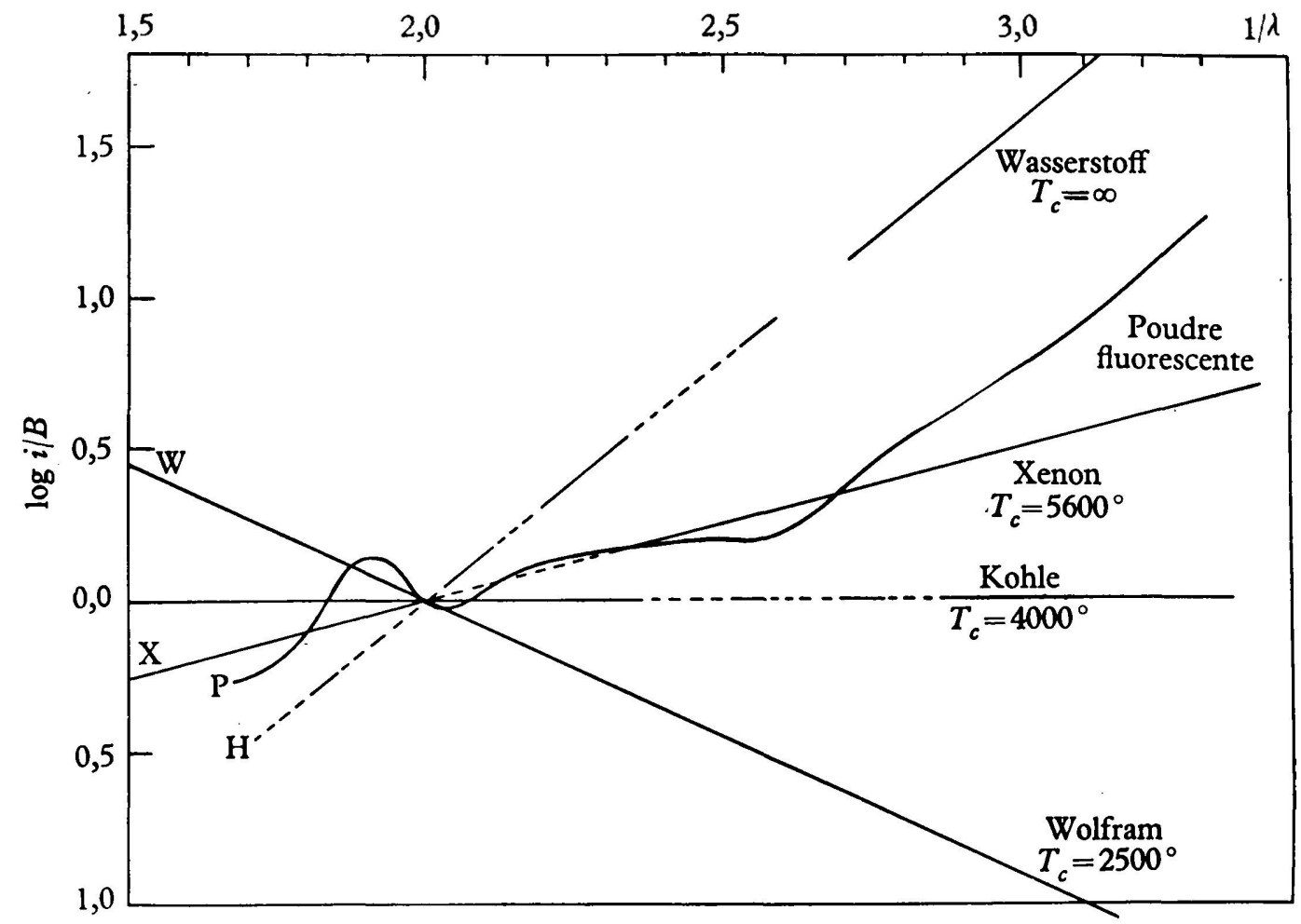

The figure shows the relative intensity distribution referred to Black-Body radiation of $T=4000^{\circ} \mathrm{K}$. The parts of the spectrum disturbed by superposed emissions are represented by broken lines.

\section{REFERENCES}

(I) King, J.O.S.A. 12, 503, x926; Henning, Temperaturmessung, Leipzig, r955; Pierce, Ap. J. II9, 3I2, I954.

(2) Kienle et al. Z. Ap. 20, 91, 194I; de Vos, Acad Proefschrift, Amsterdam, 1953.

(3) MacPherson, J.O.S.A. 30, I89, I940; Euler, Z. angew. Phys. 3, 260, I95I.

(4) Schulz, $Z$. Naturf. 2a, 583, 1947; Kienle, Vistas in Astronomy, 2, 1955; Heller, Z. AP. 38, 55, 1955 .

(5) Zeiss, Wasserstofflampe Type $H$ 30, Prospect 05-570-d.

(6) Guérin, Rev. d'Opt. 33, I37, I954. 


\section{Résumé de la Communication faite par D. Chalonge}

Sur la forme de la courbe d'énergie des spectres continus stellaires dans le domaine visible (pour les étoiles naines des types $\mathrm{O}$ à F8).

Dans tout le domaine spectral compris entre 6200 et $3900 \AA$ la courbe d'énergie des spectres continus stellaires des types F6-F 8 peut être décrite avec précision par une seule température de couleur, tout comme pour le Soleil.

Mais il n'en est plus de même pour les étoiles O ou B: pour celles-ci la courbe d'énergie n'est représentable par un gradient bien défini qu'au dessous de $4800 \AA$ environ. Si l'on se déplace de 4800 vers les plus grandes longueurs d'onde la courbe reste au dessus de celle qui correspondrait au même gradient que pour les courtes longueurs d'onde, tout en conservant plus ou moins sa direction (c'est-à-dire celle qu'elle avait pour $\lambda<4800 \AA$ ). La courbe présente ainsi une sorte de 'marche d'escalier' au voisinage de $\mathrm{H} \beta$ et cette cassure garde la même importance et une forme analogue pour toutes les étoiles moins avancées que B 5. Elle s'efface ensuite, progressivement, lorsqu'on va vers les types plus avancés, lentement d'abord, puis beaucoup plus vite lorsqu'on a dépassé le type Ao: il semble probable que cette disparition plus rapide est due à la couche opaque et absorbante d'ion négatif hydrogène qui se développe dans les étoiles plus avancées que A o mais la cause de la cassure observée reste inconnue; elle semble ne se manifester que dans les couches où la température et l'état d'ionisation sont élevés (ce phénomène n'est pas entièrement nouveau: depuis longtemps les astronomes allemands de l'école de Kienle avaient signalé que les spectres continus stellaires ne sont pas toujours représentables par un gradient absolu unique).

De grandes différences peuvent exister aussi entre les courbes d'énergie des naines et des supergéantes d'un type spectral donné pour les types de A à F, mais elles semblent pouvoir s'expliquer par la présence de quantités plus ou moins grandes d'ion $\mathrm{H}$ - dans les couches extérieures.

Deux sous naines présentent une cassure assez notable dans leur courbe d'énergie alors que les étoiles normales les plus voisines n'en présentent pratiquement pas. Le phénomène semble exister aussi, mais à un moindre degré chez les étoiles à grande vitesse (ces derniers résultats sont dus à L. Divan).

\section{Report of the Meeting of Sub-commission 36 a on Line Intensity Standards.} 30 August r955

President: Dr K. O. Wright.

Secretary: Prof. H. H. Plaskett.

The Draft Report was discussed. Particular importance was attached to the comparison between the Mt Wilson and Victoria determinations of equivalent widths in standard stars, the more so since the overwhelming bulk of the work of the Sub-commission has been carried by these two institutions. From the contributions of Dr Wright, Dr Greenstein and Dr Wrubel to the discussion it became clear that-

I. The step slit at Mt Wilson and the rotating sector at Victoria give calibration curves which are identical within the errors of measurement.

2. The errors due to a wide microphotometer slit, first pointed out by Cayrel and discussed by Deutsch, do not affect the equivalent widths as measured at Victoria. They can in any event be avoided by making the microphotometer slit comparable in width to the photographic resolving power.

3. For spectral types $\mathrm{Fo}_{\mathrm{O}}$ and earlier, and in particular for $\mathrm{I}_{5} \mathrm{Vul}$ (A 5 ) and $\sigma$ Boo $(\mathrm{Fo})$, the ratios of the equivalent widths found at Mt Wilson and Victoria are unity within the errors of measurement.

Gratifying though these results were, the President felt that the situation with respect to equivalent widths in stars of spectral type Fo and earlier would not be really satis- 
factory until measures with high dispersion had also been made by other institutions. It was agreed that a short list of standard stars, suitable for this purpose and for which line-profiles could also be measured, should be drawn up by the President and Dr Greenstein, and that every encouragement should be offered to institutions with suitable equipment to take part in this quite vital work.

The apparently insoluble problem still facing the Sub-commission concerns stars of spectral type later than Fo. Even for Procyon ( $\left.\mathrm{F}_{4}\right)$ there are difficulties, and Dr Wrubel pointed out that the line-profiles for this star obtained at Mt Wilson with a Babcock grating and at Victoria with a Bausch and Lomb grating with comparable dispersion differed markedly in the wings of the line. The profiles thus compared were obtained by himself using the methods of microphotometry currently employed at the two institutions, and in the absence of any other explanation he could only suggest that perhaps some of the differences arose from his unfamiliarity with the Babcock direct-intensity microphotometer used at Mt Wilson.

Dr Greenstein pointed out the importance in late-type spectra of using a dispersion of not less than ro $\AA / \mathrm{mm}$. With smaller dispersion weak lines in the wings of the line under examination are photographically unresolved and tend to produce too large a measured equivalent width. He also drew attention to the possibility of an asymmetrical error in determining the equivalent width of faint lines by the ordinary method of smoothing silver grain fluctuations in the microphotometer tracing; he strongly recommended the use of the technique employed at Edinburgh and Victoria for finding the equivalent widths of such lines. In his opinion the crux of the problem of finding equivalent widths of lines in late-type stars lies in finding the true continuous background, and he felt that it would be a great help if really high dispersion spectra of one or more bright stars could be obtained with solar equipment. The solar observers present at the meeting were not optimistic about the practicability of this suggestion.

Prof. Unsöld reported on recent theoretical attempts to fix the height of the continuum in late-type stars. M. Chalonge drew attention to the method of fixing the continuum in spectrophotometric gradient work, but Prof. Greaves doubted whether the accuracy of this method, which was more than adequate for the determination of a gradient, was sufficient for finding true equivalent widths.

On the motion of Dr Greenstein the Draft Report was approved.

\section{Report of meetings of Sub-commission $36 b$}

President : Dr A. Unsöld.

SECRETARY: Dr C. de Jager.

Two meetings were held, the first on Thursday, I September, the second on Saturday, 3 September.

The Chairman gave a review of the present state of the theory of stellar atmospheres, and discussed subsequently:

r. The problem of the computations of a stellar model based on the constancy of flux condition.

2. The re-emission in lines formed in hot atmospheres in which electron scattering is important; in that case the re-emission can be described as 'absorption', because of the great Doppler shifts (up to $\mathrm{I}_{5} \AA$ ) due to the electron velocities.

3. The presentation of tables and graphs of computed absorption coefficients: it is advisable to give one graph for each value of $\lambda$.

4. The influence of convection on the structure of the stellar atmospheres: it seems that the entropy of radiation generally is so small that it is not necessary to incorporate it in the computations of motions of matter in convective regions.

5. The hydrodynamic phenomena which arise when the mean turbulent velocity, increasing with height, equalizes the velocity of sound; then: $(a)$ the hydrodynamic 
velocities become of the same order as the atomic velocities; $(b)$ the turbulent pressure is of the same order as the gas pressure; $(c)$ the pressure fluctuations $\Delta P$ are of the same order as the value of $P$; and $(d)$ temperature fluctuations in adjacent volumes of matter up to $1000^{\circ}$ or more (in the Sun) may occur. This shows the need for inhomogeneous models of the solar and stellar atmospheres.

6. The influence of magnetic fields on stellar atmospheres: the magnetic pressure and energy are generally small as compared with the hydrodynamic pressure and energy.

7. The computation of line profiles and curves of growth; for general use it is advisable to compute curves of growth for true absorption.

8. The practical way of computing a stellar atmosphere in the subsequent steps: (a) coarse analysis; $(b)$ computation of more precise model ( $F$ constant); $(c)$ correction with differential formula; $(d)$ final model.

Pecker remarked that theorists should discuss their observations in the same way as the observers do; an example is given for the Balmer jump intensity, where the measured intensity has not the same meaning as the computed one. Miss Underhill expressed doubt as to the value of the constancy-of-flux condition in computing a model atmosphere: great temperature fluctuations can correspond to small $\Delta F$-values. Minnaert gave a report of the work of the informal commission for the computation of tables of data important for stellar atmospheres. The Commission was established in Rome, I952; since, preparatory work has been done especially by Pecker. Minnaert's proposal was accepted, that Pecker should first compute for one or two elements the partition function according to a scheme, established by Pecker and sent to members of the Commission. The results will be sent to the members of the Commission for their comments.

As to the problem of the widening of the Balmer lines, Unsöld remarked that the experimental results obtained in Michigan and Kiel do not refer to conditions prevailing in stellar atmospheres. Great deviations from the classical Holtzmark mechanism are not to be expected in normal stellar atmospheres. It is essential for the interpretation of a spectrum that the parameters $T_{\text {eft. }}$ and $g$ be determined with great accuracy. The problem is to use the observational material in such a way as to find a unique solution. Menzel stressed that $T_{\text {efr }}$ and $g$ are parameters only; in a realistic physical model of an atmosphere dynamical concepts should also be introduced; not only convection but also electro-magnetic phenomena. 